\title{
Development of Discrete Components
}

Kansas City Division

R. J. Brown

KCP-613-5640
RECEIVED

DEC 07.1995

OSTI

\section{Published November 1995}

\section{Final Report}

Approved for public release; distribution is unlimited.

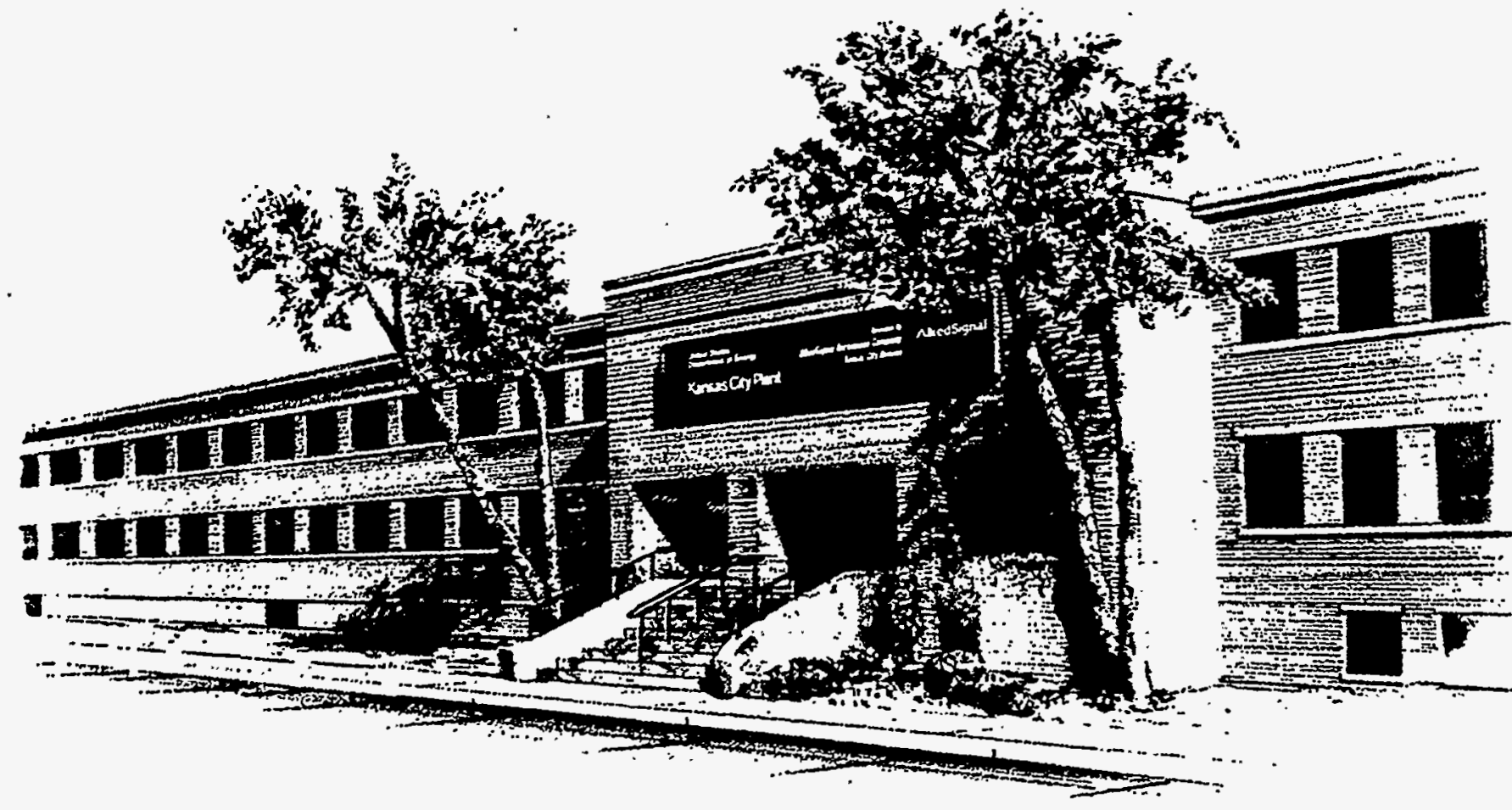




\section{DISCLAIMER}

This report was prepared as an account of work sponsored by an agency of the United States Government. Neither the United States Government nor any agency thereof, nor any of their employees, makes any warranty, express or implied, or assumes any legal liability or responsibility for the accuracy, completeness, or usefulness of any information, apparatus, product, or process disclosed, or represents that its use would not infringe privately owned rights. Reference herein to any specific commercial product, process, or service by trade names, trademark, manufacturer, or otherwise, does not necessarily constitute or imply its endorsement, recommendation, or favoring by the United States Government or any agency thereof. The views and opinions of authors expressed herein do not necessarily state or reflect those of the United States Government or any agency thereof.

All data prepared, analyzed and presented has been developed in a specific context of work and was prepared for internal evaluation and use pursuant to that work authorized under the referenced contract. Reference herein to any specific commercial product, process or service by trade name, trademark, manufacturer, or otherwise, does not necessarily constitute or imply its endorsement, recommendation, or favoring by the United States Government, any agency thereof or AlliedSignal inc.

Printed in the United States of America.

This report has been reproduced from the best available copy.

Available to DOE and DOE contractors from the Office of Scientific and Technical Information, P. O. Box 62, Oak Ridge, Tennessee 37831; prices available from (615) 576-8401, . FTS 626-8401.

Available to the public from the National Technical Information Service, U. S. Department of Commerce, 5285 Port Royal Rd., Springfield, Virginia 22161. 


\title{
DEVELOPMENT OF DISCRETE COMPONENTS
}

\author{
R. J. Brown \\ Published November 1995 \\ Final Report \\ R. J. Brown, Project Leader
}




\section{Contents}

Section

Page

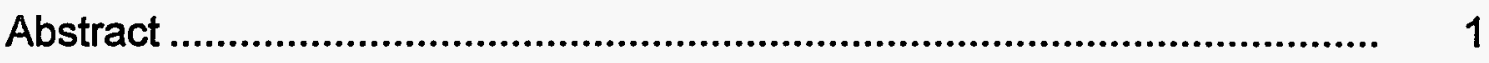

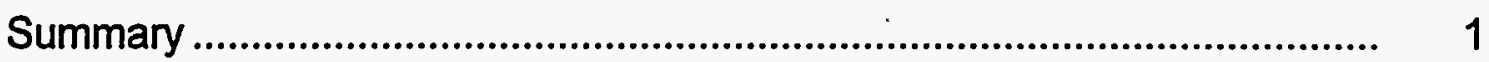

Discussion ................................................................................. 2

Scope and Purpose ................................................................ 2

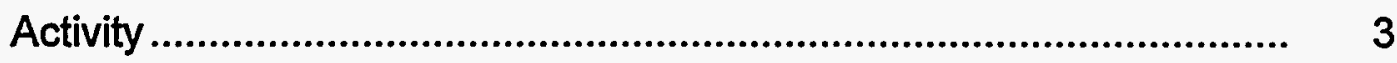

Wire Bond Integrity ..................................................................

Die Attach Integrity ............................................................. 5

Radiation Margin of Current Devices........................................ 6

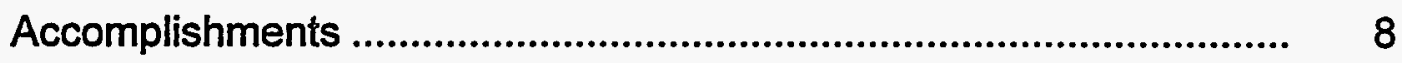

Appendices

A. 2N2484 Type Post-Neutron $\mathrm{h}_{\mathrm{FE}}$ Performance at

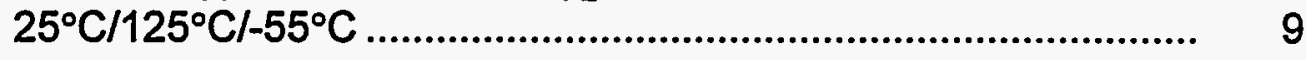

B. 2N2907A Type Post-Neutron $\mathrm{h}_{\mathrm{FE}}$ Performance at

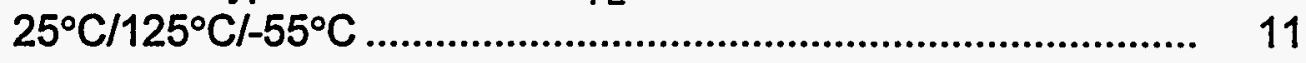

C. 2 N5339 Type Post-Neutron $\mathrm{h}_{\mathrm{FE}}$ Performance at

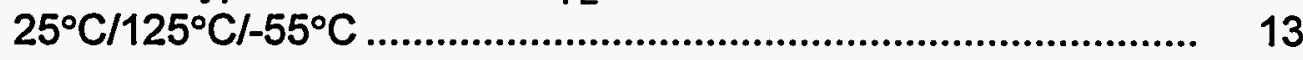




\section{Illustrations}

Title

Page

$1 V_{B E}$ vs. Cumulative Hours of Aging at $200^{\circ} \mathrm{C}\left(I_{B}=I_{E}=0.2\right.$ Amp $) \ldots \ldots . .4$

$2 V_{B E}$ vs. Cumulative Hours of Aging at $200^{\circ} \mathrm{C}\left(I_{B}=I_{E}=0.5\right.$ Amp $) \ldots \ldots . .4$

$3 V_{B E}$ vs. Cumulative Hours of Aging at $200^{\circ} \mathrm{C}\left(I_{B}=I_{E}=1.0\right.$ Amp $) \ldots \ldots . .4$

$4 \quad V_{B E}$ vs. Temperature for Increments of Collector Current, $I_{M} \ldots \ldots \ldots \ldots . . . . \quad 5$

$5 \Delta \mathrm{V}_{\mathrm{BE}}$ Vs. $\log _{10}$ (Time) for Varying Wattage $\left(\mathrm{V}_{\mathrm{CE}} \times \mathrm{I}_{\mathrm{H}}\right)$ Input Levels ...... 6

$6 \quad \Delta \mathrm{V}_{\mathrm{BE}}$ Vs. Time for Varying Wattage $\left(\mathrm{V}_{\mathrm{CE}} \times \mathrm{I}_{\mathrm{H}}\right)$ Input Levels................... 6

7 Pre- and Post-Neutron VCE(sat) Performance of the Previous 2N2907A Type.

8 Pre-and Post-Neutron $V_{C E}$ (sat) Performance of the Current 2N2907A Type.

A-1 2N2484 Type Post-Neutron $h_{F E}$ Performance at $+25^{\circ} \mathrm{C} \ldots \ldots \ldots \ldots \ldots \ldots . . . . . . . . .10$

A-2 2N2484 Type Post-Neutron $h_{\mathrm{FE}}$ Performance at $+125^{\circ} \mathrm{C} \ldots \ldots \ldots \ldots \ldots \ldots . . . . . .10$

A-3 2N2484 Type Post-Neutron $h_{\mathrm{FE}}$ Performance at $-55^{\circ} \mathrm{C} \ldots \ldots \ldots \ldots \ldots \ldots . . . . . . . . . . .10$

B-1 2N2907A Type Post Neutron $h_{F E}$ Performance at $+25^{\circ} \mathrm{C} \ldots \ldots \ldots \ldots \ldots . . . . . . . .12$

B-2 2N2907A Type Post Neutron $h_{\mathrm{FE}}$ Performance at $+125^{\circ} \mathrm{C} \ldots \ldots \ldots \ldots \ldots . . . . .12$

B-3 2N2907A Type Post Neutron $h_{\mathrm{FE}}$ Performance at $-55^{\circ} \mathrm{C} \ldots \ldots \ldots \ldots \ldots \ldots . . . . . . . .12$

C-1 2 N5339 Type Post-Neutron $h_{\mathrm{FE}}$ Performance at $+25^{\circ} \mathrm{C} \ldots \ldots \ldots \ldots \ldots \ldots . . . . . . . . .14$.

C-2 2 N5339 Type Post-Neutron $h_{\text {FE }}$ Performance at $+125^{\circ} \mathrm{C} \ldots \ldots \ldots \ldots \ldots \ldots . . . . . . .14$

C-3 2 N5339 Type Post-Neutron $h_{F E}$ Performance at $-55^{\circ} \mathrm{C} \ldots \ldots \ldots \ldots \ldots \ldots \ldots . . . . . . . . . .14$ 


\section{Tables}

Number Page

1 Header Gold Thickness Comparison ..................................................... 3

2 Post-Aging Bond Pull Strength ............................................................ 4

3 Thermal Impedance Test Sequence ............................................... 5

4 Current Supplier Die Types Selected for Radiation Testing ................. 6

5 Allocation of Device Samples for Radiation Testing ........................... 7 



\begin{abstract}
AlliedSignal, Inc., Kansas City Division, the production agency, was provided with funding to maintain the capability to procure discrete components for various applications. A development project was undertaken to procure transistor die from one supplier for assembly into finished components by a different supplier. These components would be "SA-equivalent" with appropriate preconditioning, testing, and certification. The methodologies developed herein go far to ensure the future availability of discrete components.
\end{abstract}

\title{
Summary
}

During periods of reduced military procurement, semiconductor suppliers who traditionally maintained production capacity for military products have converted significant portions of this capacity to commercial use. In order to maintain the capability to procure components, a project was undertaken to examine the feasibility of third-party packaging for Sandia apparatus (SA) devices.

Assembly concerns regarding bond wire and die attach integrity were eliminated as a result of this project. Initial radiation testing, however, revealed that the packaging supplier's current small-signal die is significantly less tolerant than that of the previous manufacturer.
With the assembly concerns eliminated, the result has been a highly agile packaging capability which goes far to ensure the future availability of discrete components fabricated using previously-qualified die.

Future work, in conjunction with Sandia Laboratories and the packaging supplier, will likely be focused on improving the radiation tolerance of both the supplier's small-signal and power die. 


\section{Discussion}

\section{Scope and Purpose}

This project, Development of Discrete Components, was initiated due to continuing decline in the number of suppliers qualified to manufacture SA discrete transistor components. Specific business policy changes by suppliers directly affecting the procurement of SA transistors included 1) standardization of dual-use (joint commercial and military) specifications for component lead material which allowed solder dip over defect-prone electroless nickel plating; 2) reluctance to accept sourcecontrolled drawings (SCDs); 3) elimination of "sunset technologies" devices through "life-oftype buys;" and 4) introduction of plasticencapsulated devices as replacements for hermetic military products.

These directions posed significant concerns due to the variety of weapon systems in the stockpile built using SA devices. In addition, the need for replacement devices was being driven by ongoing retrofit and telemetry programs.

As a result, this project was initiated with the intent of qualifying a third-party packaging facility to manufacture SA transistors. The supplier previously had wafer fabrication capability and was approved by Defense Electronics Supply Center (DESC) to supply Joint Army-Navy (JAN) product. This project was designed to be the vehicle whereby this supplier could eventually build SA devices using the supplier's own die.
This nontraditional approach posed increased risk for both the user [AlliedSignal Inc., Kansas City Division (ASKCD)] and the thirdparty packaging supplier. First, the user must ensure that high-quality die is available. Second, the packaging supplier must often develop alternate processes for wire bonding and die attach to accommodate foreign die. Third, the user must realize that third-party packaging is an effective but temporary solution. Suppliers who have exited the military semiconductor business generally loose all expertise in the production of radiation-tolerant and radiation-hardened devices.

Since both Sandia Laboratories and ASKCD had significant prior experience with qualified die, further investigations of the die itself were not required. The remaining areas of risk involved in the packaging of die at a thirdparty supplier were determined to be:

- wire bond integrity,

- die attach integrity, and

- radiation margin of current die.

The assembly-related results obtained from these investigations were incorporated into product and assembly specifications used in actual assembly of SA devices. Nonproduction activities are reported herein. 


\section{Activity}

\section{Wire Bond Integrity}

The supplier's initial focus was on header characteristics. The gold plating typically used on an SA device was thinner than that produced by the supplier's header source as shown in Table 1.

Table 1. Header Gold Thickness Comparison

\begin{tabular}{llll}
\hline Location & $\begin{array}{l}\text { Supplier } \\
\text { Source } \\
\text { Plating } \\
\text { Thickness } \\
\text { (microns) }\end{array}$ & $\begin{array}{l}\text { Typical SA } \\
\text { Device } \\
\text { Plating } \\
\text { Thickness } \\
\text { (microns) }\end{array}$ & $\begin{array}{l}\text { - Thickness } \\
\text { Ratio } \\
\text { (Supplier: } \\
\text { Typical } \\
\text { SA) }\end{array}$ \\
\hline Header & 3.52 & 2.60 & $1.35: 1$ \\
Post & 3.20 & 2.08 & $1.54: 1$ \\
Leads & 5.28 & 3.08 & $1.71: 1$ \\
\hline
\end{tabular}

An accelerated aging evaluation was conducted to determine the severity of purple plague formation on devices assembled with headers containing relatively thick gold. The expected outcome was that thick gold under the aluminum wire bond would accelerate the formation of gold-aluminum intermetallics at elevated temperatures.

It was considered that activation energies above $150^{\circ} \mathrm{C}$ might be significantly different from those at temperatures above $300^{\circ} \mathrm{C}$. An acceleration aging temperature of $200^{\circ} \mathrm{C}$ was selected to provide margin over the $150^{\circ} \mathrm{C}$ HTRB temperature normally seen during preconditioning. The intent was to not introduce temperature-dependent activation energy concerns into the evaluation.
Three approaches were used to conduct this evaluation: nondestructive electrical contact resistance, destructive bond pull, and final visual.

\section{Electrical Contact Resistance Testing}

Backside collector die attach construction places both base and emittèr wires in contact with the posts. Test equipment was programmed to pass a constant base current through the base-emitter junction during which time $\mathrm{V}_{\mathrm{BE}}$ was measured. The $\mathrm{V}_{\mathrm{BE}}$ measurement reflects the lumped resistance of the base-emitter diode bulk, bond wire, and post contact. The assumption was made that at sufficiently high currents, the effects of intermetallic formation could be seen as an increase in contact resistance manifested by proportional increases in $V_{\mathbf{B E}}$.

A sample of ten devices packaged without preconditioning was first tested to verify conformance to room temperature electrical specifications. Eight of the ten devices, serial numbers $1-8$, were baked in an oven at $200^{\circ} \mathrm{C}$ for four hours. Following a 30 -minute minimum cool-down period to room temperature, each device was subjected to base-emitter current pulses of $0.2,0.5$, and 1.0 amperes. Reverse leakage current $\left(l_{E B O}\right)$ measurements were performed. Results were compared pre- and post-pulse to verify that the junction had not been damaged due to the current pulse. Two devices, serial numbers 9 and 10 , were used as control devices and not exposed to elevated temperature.

The bake cycle was repeated an additional six times for a total exposure of 28 hours at $200^{\circ} \mathrm{C}$. The experimental activation energy for gold-aluminum intermetallic formation is in the vicinity of $1.0 \mathrm{eV}$. Using this estimated figure, each 4-hour bake would represent approximately 5 years of continuous field 
operation at a field junction temperature of $70^{\circ} \mathrm{C}$.

Figures 1, 2, and 3 show maximum, mean, and minimum values of $V_{B E}$ based on measurements of the eight samples over the 28-hour period.

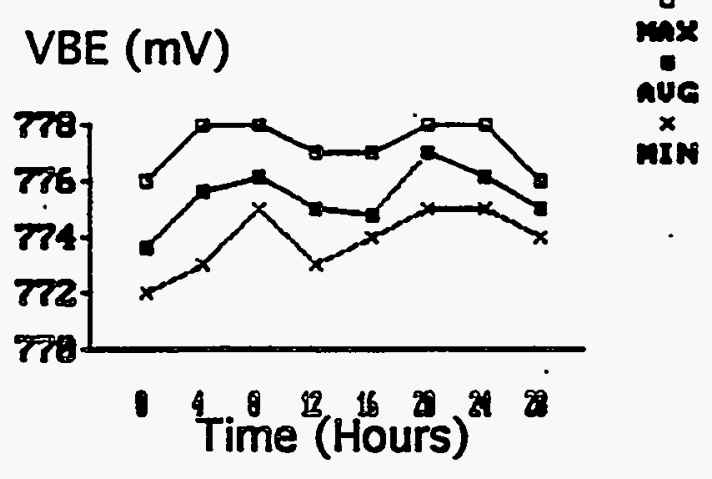

Figure 1. $\mathrm{V}_{\mathrm{BE}}$ vs. Cumulative Hours of Aging at $200^{\circ} \mathrm{C}\left(I_{B}=I_{E}=0.2 \mathrm{Amp}\right)$

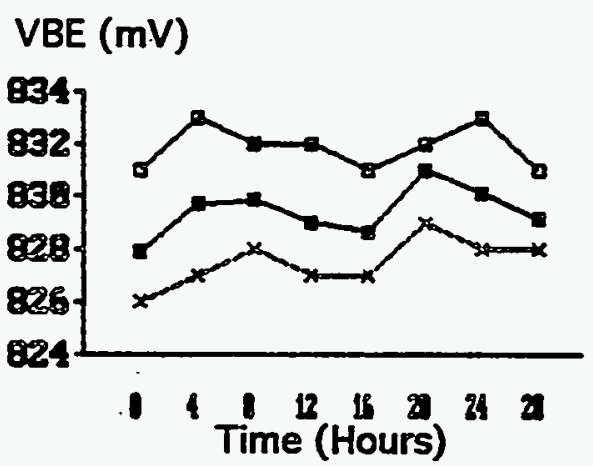

Figure 2. $V_{B E}$ Vs. Cumulative Hours of Aging at $200^{\circ} \mathrm{C}\left(I_{B}=I_{E}=0.5 \mathrm{Amp}\right)$

Results from pulses of 0.2 and 0.5 ampere, Figures 1 and 2 respectively, are similar. $A$ distinction can seen in Figure 3 for the 1.0-ampere pulse. The sample minimum value of $V_{B E}$ increased linearly for the first 8 hours and then stabilized.

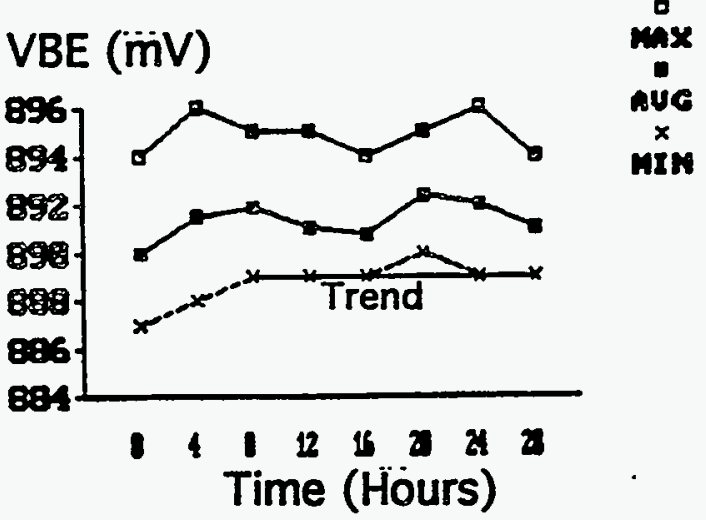

Figure 3. $\mathrm{V}_{\mathrm{BE}}$ VS. Cumulative Hours of Aging at $200^{\circ} \mathrm{C}\left(I_{B}=I_{E}=1.0 \mathrm{Amp}\right)$

\section{Bond Pull Strength Testing}

Post-aging bond pull strength was tested in accordance with MIL-STD-750, Method 2037. The intent was to pull each wire to destruction with particular attention paid to any separations which occurred at the posts. These results are shown in Table 2.

Table 2. Post-Aging Bond Pull Strength ${ }^{2}$

\begin{tabular}{lll}
\hline $\begin{array}{l}\text { Serial } \\
\text { Number }\end{array}$ & $\begin{array}{l}\text { Wire \#1 } \\
\text { Strength } \\
\text { (grams) }\end{array}$ & $\begin{array}{l}\text { Wire \#2 } \\
\text { Strength } \\
\text { (grams) }\end{array}$ \\
\hline 1 & 243 & 243 \\
2 & 242 & 243 \\
3 & 242 & 242 \\
4 & 242 & 242 \\
5 & 243 & 243 \\
6 & 242 & 242 \\
7 & 244 & 242 \\
8 & 245 & 244 \\
9 (Control) & 244 & 242 \\
10 (Control) & $119^{\mathrm{b}}$ & $121^{\mathrm{b}}$ \\
\hline
\end{tabular}

NOTES:

a. No separations occurred at the post.

b. These samples were the first tested and a 100 -gram beam was used. The minimum post-seal pull sirength for 10-mil wire in accordance with Mil-Std-750, Method 2037, is 80 grams. A larger beam was used on the remaining samples to. improve accuracy. Due to equipment limitations, actual readings may be beyond those recorded. 


\section{Die Attach Integrity}

Thermal impedance (commonly referred to as "Sage testing") is a nondestructive die attach evaluation technique. For bipolar transistors, $V_{B E}(O n)$ is the temperature-sensitive parameter. The $\mathrm{V}_{\mathrm{BE}}(\mathrm{On})$ is initially measured on a sample of devices over a temperature range to establish correlation coefficients.

All measurements are performed on an independent semiconductor tester programmed to a low duty cycle at the measuring current to minimize self-heating during correlation. Parametric $V_{B E}(O n)$ variation between individual devices from the same wafer or wafer lot is typically insignificant. The average value of $\mathrm{V}_{\mathrm{BE}}(\mathrm{on})$ when plotted on linear graph paper against temperature (Figure 4) is a straight line whose slope is the temperature coefficient for the device at measuring current $I_{M}$.

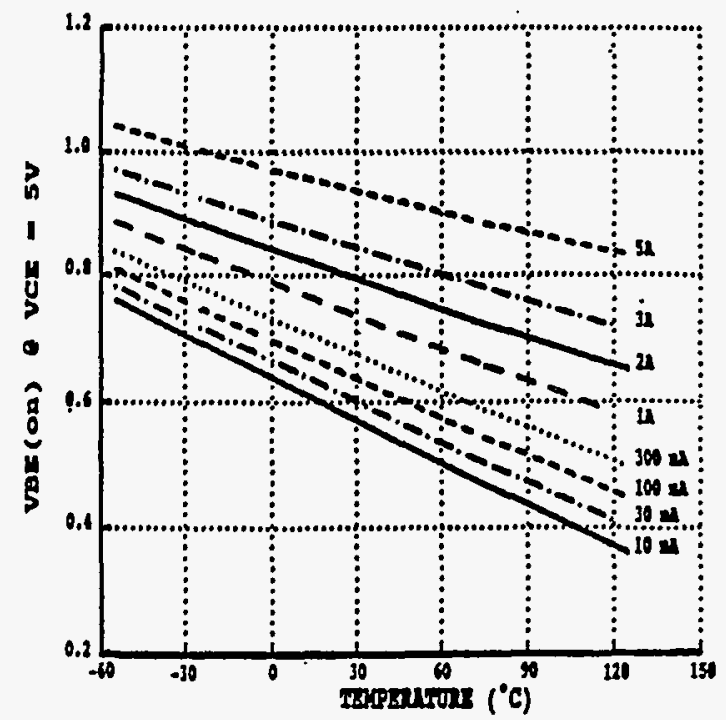

Figure 4. $V_{B E}$ VS. Temperature for Increments of Collector Current, $I_{M}$

Through use of thermal impedance testing, $\Delta \mathrm{V}_{\mathrm{BE}}$ can be correlated to both transient and steady. state heat flow characteristics. These characteristics are an inherent signature of die adhesion, assembly materials, and heat transfer properties of a given die in a given package.

During thermal impedance testing, the device is turned on by $I_{M}$, maintained on by heating current $I_{H}$ for $t_{H}$ seconds, turned off, and turned on for the final time by $I_{M}$. This technique is further defined by Table 3 .

Table 3. Thermal Impedance Test Sequence

\begin{tabular}{|c|c|c|c|}
\hline Time & Event & Effect & $\begin{array}{l}\text { Measure- } \\
\text { ment or } \\
\text { Compu- } \\
\text { tation. }\end{array}$ \\
\hline$t_{0}$ & & $\begin{array}{l}\text { Device junction } \\
\text { is at room } \\
\text { ambient }\end{array}$ & None \\
\hline$t_{1}$ & Apply $I_{M}$ & & $\begin{array}{l}\text { Measure } \\
V_{\mathrm{BE}(\mathrm{On})_{1} \text { at near }} \\
\text { ambient }\end{array}$ \\
\hline$t_{2}$ & $\begin{array}{l}\text { Apply } I_{H} \text { for } \\
t_{H} \text { seconds } \\
\left(I_{H} \gg>I_{M}\right)\end{array}$ & $\begin{array}{l}\text { Junction } \\
\text { temperature } \\
\text { increases as a } \\
\text { function of } I_{H} \\
\text { and } t_{H}\end{array}$ & $\begin{array}{l}\text { Measure on } \\
\text { voltage at } l_{H}\end{array}$ \\
\hline$t_{3}$ & $\begin{array}{l}\text { Drop } I_{H} \text { and } \\
\text { reverse } \\
\text { bias } \\
\text { junction : }\end{array}$ & $\begin{array}{l}\text { Quit heating and } \\
\text { remove excess } \\
\text { charge from } \\
\text { junction }\end{array}$ & None \\
\hline$t_{4}$ & $\begin{array}{l}\text { Wait for } \\
\text { several } \\
\text { micro- } \\
\text { seconds }\end{array}$ & $\begin{array}{l}\text { Allow transients } \\
\text { to decay before } \\
\text { junction starts to } \\
\text { cool }\end{array}$ & None \\
\hline$t_{5}$ & Reapply $I_{M}$ & $\begin{array}{l}\text { Device junction } \\
\text { temperature a } \\
\text { function of heat } \\
\text { retained in } \\
\text { package }\end{array}$ & $\begin{array}{l}\text { Measure } \\
\mathrm{V}_{\mathrm{BE}}(\text { on })_{2} \text { at } \\
\text { elevated } \\
\text { temperature and } \\
\text { compute } \\
\Delta \mathrm{V}_{\mathrm{BE}}(\mathrm{on})= \\
\mid \mathrm{V}_{\mathrm{BE}}(\text { on })_{1}- \\
\mathrm{V}_{\mathrm{BE}}(\text { on })_{2} \mid\end{array}$ \\
\hline
\end{tabular}


To make optimal use of thermal impedance testing, heating time $\left(t_{H}\right)$ must be adjusted to reflect the thermal time constant of the die attach region. This heat transfer region and others of interest are depicted in Figure 5.

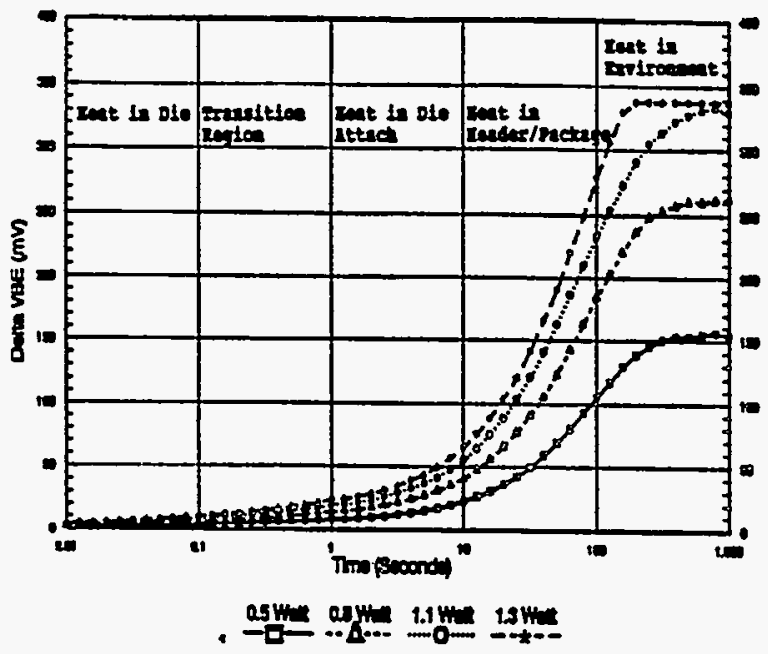

Figure 5. $\Delta \mathbf{V}_{\mathrm{BE}}$ Vs. $\log _{10}$ (Time) for Varying Wattage $\left(V_{C E} \times I_{H}\right)$ Input Levels

Of note, the time axis of Figure 5 is plotted on a logarithmic scale. This is standard practice for representation of the heat transfer characteristic. The problem, however, is one of determining where the transition region ends and the die attach region begins.

One graphical solution is to re-plot both axes of Figure 5 on linear scales as shown in Figure 6 . Hence, a distinction can be made via the logarithmic die heat transfer characteristic giving way to the piece-wise linear die attach transition characteristic. In this case, $a t_{H}$ of 1.5 seconds would be recommended to detect any potential die attach concern. Testing at a power input of 1.0 watt or greater would be adequate to provide the needed resolution for pass-fail determination by the thermal impedance tester.

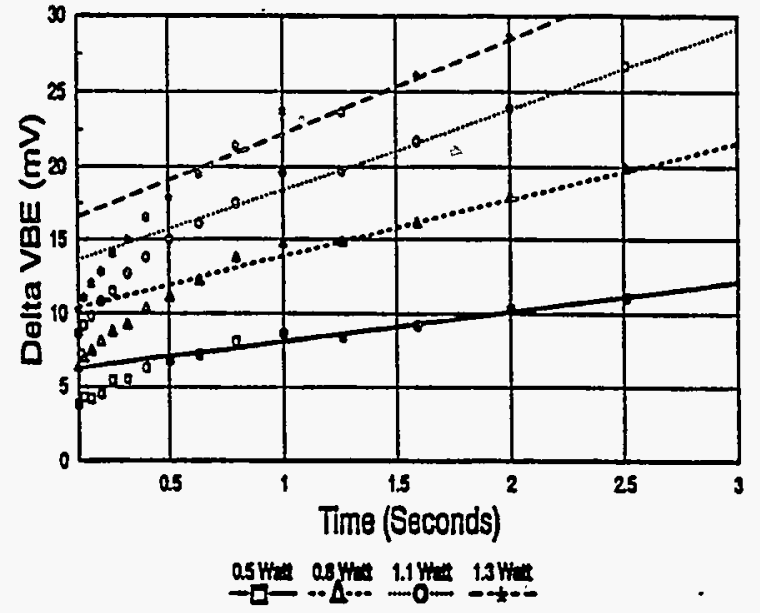

Figure 6. $\Delta V_{\mathrm{BE}}$ vs. Time for Varying Wattage $\left(V_{C E} \times I_{H}\right)$ input Levels

\section{Radiation Margin of Current Devices}

In order to establish radiation margin of the supplier's die, radiation testing was performed in the final phase of this project. Representative device types were selected as shown in Table 4.

Table 4. Current Supplier Die Types Selected for Radiation Testing

Type Polarity Category

\begin{tabular}{lll}
\hline 2N2484 & NPN & Small-signal \\
2N2907A & PNP & Small-signal \\
2N5339 & NPN & Power
\end{tabular}

Initial electrical measurements were performed on groups of 50 devices from each devices from each device iype. Samples for radiation testing were allocated as shown in Table 5. 
Table 5. Allocation of Device Samples for Radiation Testing $(n=50)$

\begin{tabular}{lc}
\hline $\begin{array}{l}\text { Radiation Test/ } \\
\text { Controls/Spares }\end{array}$ & Quantity \\
\hline Neutron & 20 \\
Total dose gamma & 5 \\
Photocurrent & 5 \\
Controls & 10 \\
Spares & 10 \\
\hline
\end{tabular}

\section{Neutron Testing}

Neutron testing on the three device types was performed at Sandia National Laboratories' SPR III facility in Albuquerque, New Mexico. As with all radiation testing, results obtained are dependent on both the facility and established test procedures for that facility. The devices received pre-radiation electrical tests at $+25^{\circ} \mathrm{C},+125^{\circ} \mathrm{C}$ and $-55^{\circ} \mathrm{C}$. Posiradiation electrical testing was performed in the sequence of $+25^{\circ} \mathrm{C},-55^{\circ} \mathrm{C}$ and $+125^{\circ} \mathrm{C}$ to preclude temperature-related annealing effects. The devices were irradiated to a target fluence of $1 E 14$ neutrons $/\left(\mathrm{cm}^{2} \mathrm{~s}\right)$, $E>1 \mathrm{MeV}$ silicon equivalent. The actual dosage received was 10.9E13 (1.09E14).

The most significant number of electrical limit failures occurred post-neutron. All three current device types failed the maximum $V_{C E}$ (sat) limit. Of the three devices tested, the 2N2907A type manufactured by the previous supplier had been fully characterized by Sandia Laboratories for post-neutron $V_{C E}$ (sat) performance at levels from $8.9 E 12$ to 1.9E14.

Figure 7 shows the pre- and post-neutron $V_{C E}$ (sat) versus collector current characteristic of the previous manufacturer's 2N2907A type. The curve at 9.7E13 or approximately $1 \mathrm{E} 14$ was used to spotcompare post-neutron $V_{C E}$ (sat) performance to that of the current supplier's 2N2907A type depicted in Figure 8.

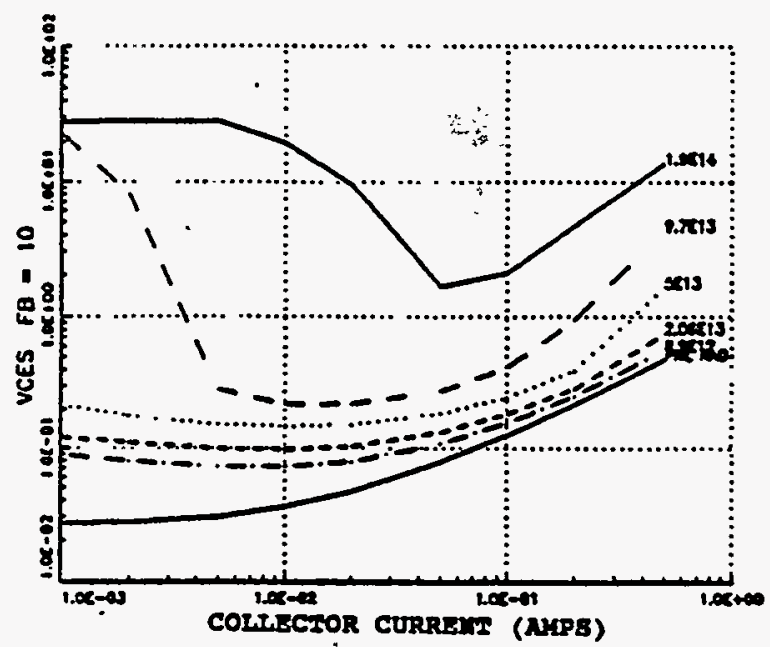

Figure 7. Pre- and Post-Neutron $V_{C E}$ (sat) Performance of the Previous 2N2907A Type

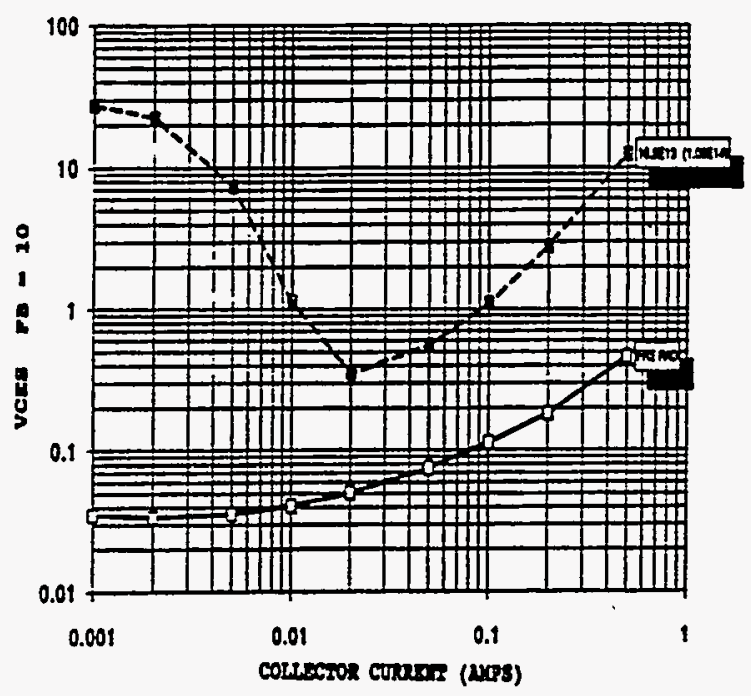

Figure 8. Pre-and Post-Neutron $V_{C E}$ (sat) Performance of the Current 2N2907 Type 
The consistency of these results provided additional assurance that no significant testing anomalies had occurred during or following neutron exposure.

The post-neutron $D C$ current gain $\left(h_{\mathrm{FE}}\right)$ characteristics of all three devices were then plotted against type data available from Sandia. Obsolete devices, devices from the previous supplier as well the current devices, are compared in the graphs at ambient, hot, and cold as shown in Appendices A, B, and $\mathrm{C}$.

\section{Total Dose Testing}

The three device types were irradiated at a target total dose of 1000 krads (Si) at Alliance Technologies' Gamma Cell (Cobalt-60) in Albuquerque. Dosimetry was measured with multiple thermoluminescence dosimeters (TLDs) during three shots of $333.33 \mathrm{krads}$ each. The test strategy was to achieve an acceptable accuracy/cost tradeoff by limiting the number of shots. Dosimetry readings taken by Sandia's Dosimetry Laboratory were higher than the levels targeted by Alliance Technologies. TLDs, however, may be inaccurate for individual shots exceeding 100 krads. The average TLD readings were 355,486 , and 513 krads per shot for a total dose of 1,354 krads.

The 2N2484 type devices showed limit failures of $V_{C E}$ (sat) during post-gamma electrical testing. The other two device types showed no failures.

\section{Photocurrent Testing}

The devices were transported by Alliance Technologies to Boeing's Radiation Effects
Laboratory in Seattle, Washington. A linear accelerator (LINAC) was used to expose the devices to target dose rate of $1 \mathrm{E} 8 \mathrm{rads} / \mathrm{s}(\mathrm{Si})$ at a $4-\mu \mathrm{s}$ pulse width. Dosimetry readings indicated that the actual dose was acceptably close to the targeted dose rate.

Post-LINAC electrical testing showed no electrical failures on any of the three device types.

\section{Accomplishments}

Initial concerns raised by the current supplier regarding header gold plating thickness for wire bond integrity were shown not to be of significance. High temperature aging, postaging bond pull testing, and visual examinations based on representative samples yielded acceptable results.

Thermal impedance test methods were improved to focus exclusively on the die attach region. As this method is nondestructive, $100 \%$ thermal impedance to be gradually replaced by sampled process monitors could be established as part of the supplier's assembly process control. Incorporation of thermal impedance testing would significantly reduce the risk of die aftach concerns raised by utilization of foreign die.

Radiation testing of the current types revealed that the 2N2484 and 2N2907A device types are more susceptible to $h_{F E}$ (gain) degradation when compared to previous device types at levels near 1E14. The 2N5339 may have sufficient tolerance for tactical applications. It is useless (peak $h_{\mathrm{FE}}<2$ at $-55^{\circ} \mathrm{C}$ ) for strategic applications at levels of 1E14 or greater. 


\section{Appendix A \\ 2N2484 Type Post-Neutron $h_{\mathrm{FE}}$ Performance at $25^{\circ} \mathrm{C} / 125^{\circ} \mathrm{C} /-55^{\circ} \mathrm{C}$}




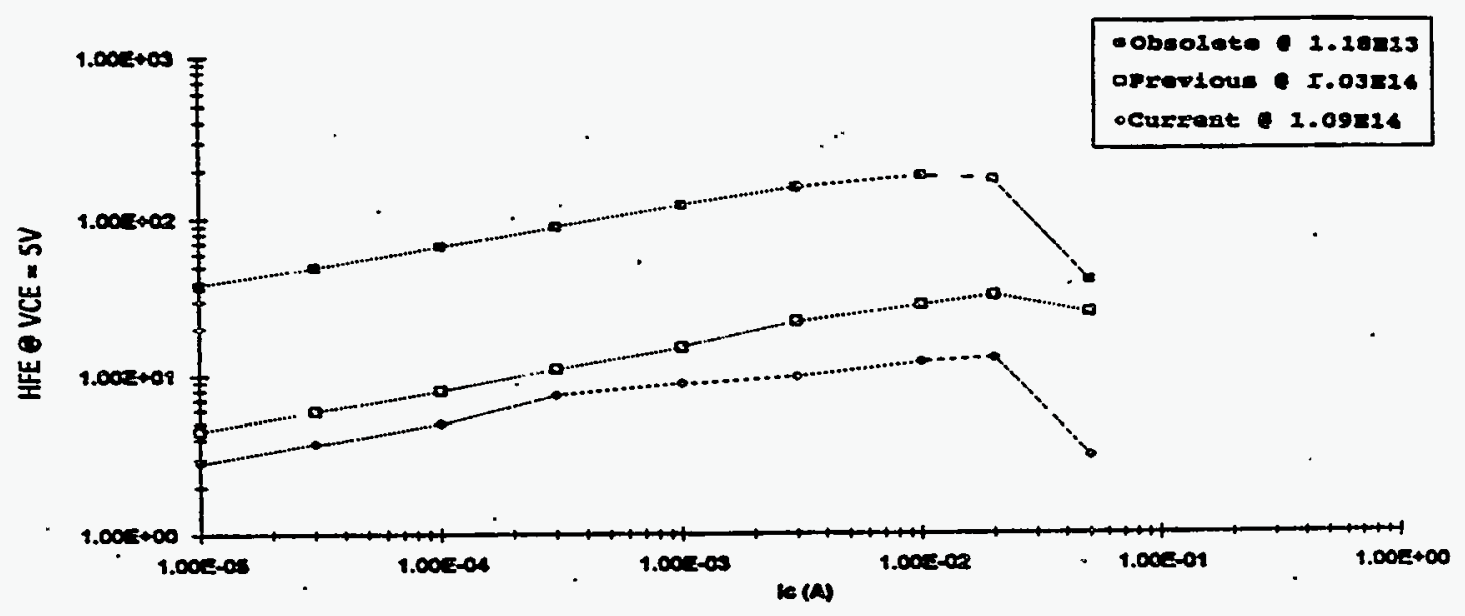

Figure A-1. 2N2484 Type Post-Neutron $h_{\mathrm{FE}}$ Performance at $+25^{\circ} \mathrm{C}$

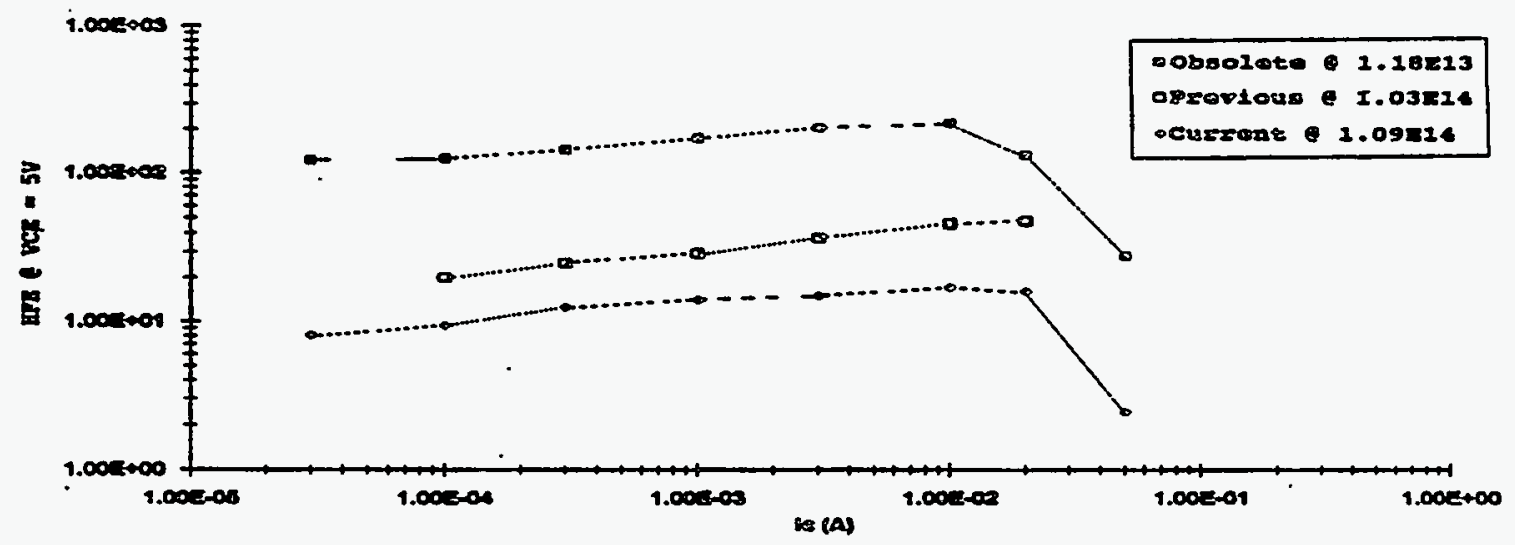

Figure A-2. 2N2484 Type Post-Neutron $h_{\mathrm{FE}}$ Performance at $+125^{\circ} \mathrm{C}$

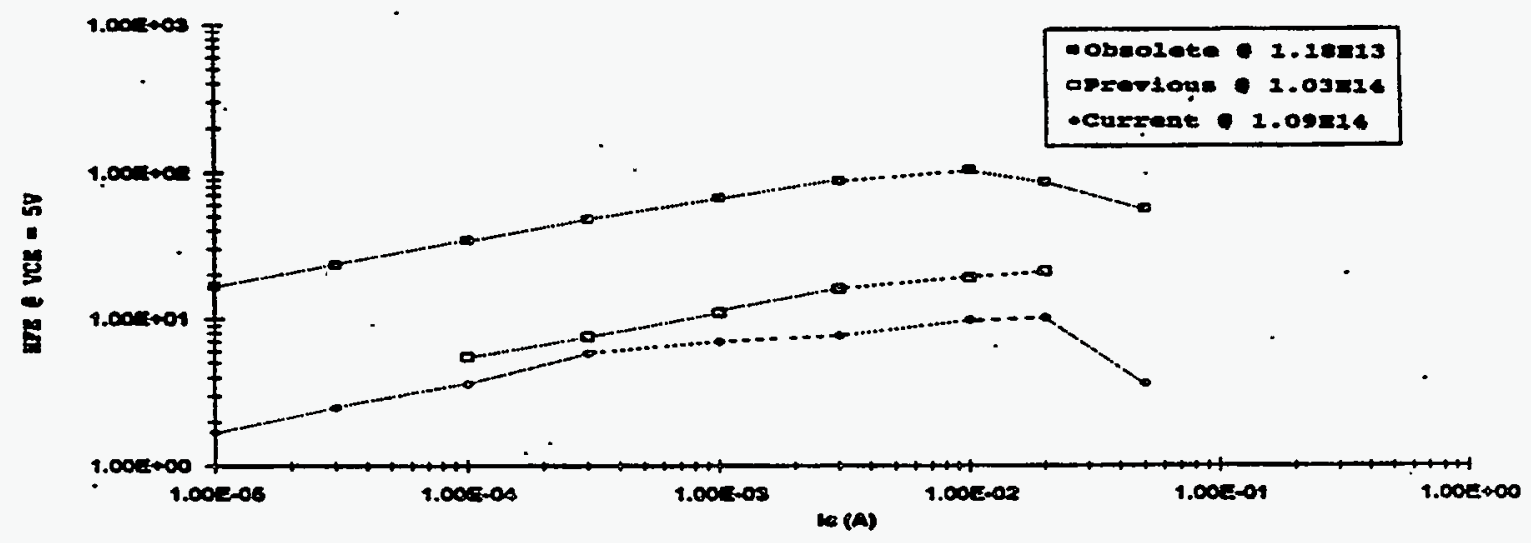

Figure A-3. 2N2484 Type Post-Neutron $h_{\mathrm{FE}}$ Performance at $-55^{\circ} \mathrm{C}$ 


\section{Appendix B}

2N2907A Type Post-Neutron $h_{F E}$ Performance at $25^{\circ} \mathrm{C} / 125^{\circ} \mathrm{C} /-55^{\circ} \mathrm{C}$ 


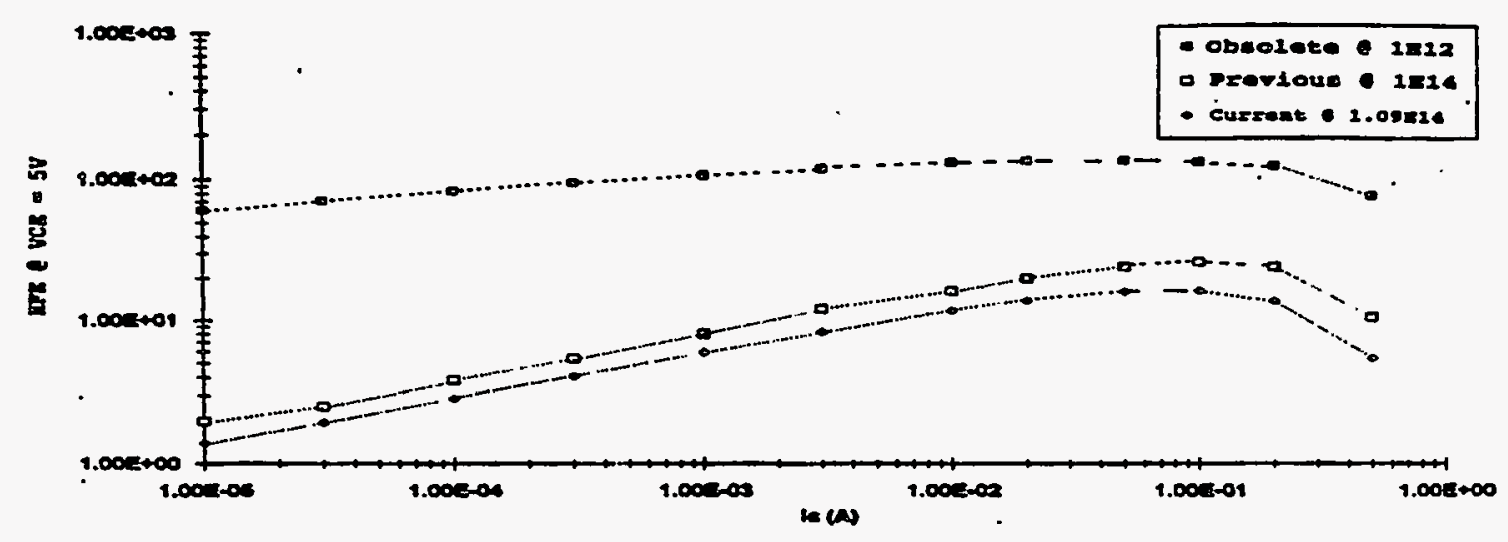

Figure B-1. 2N2907A Type Post-Neutron $\mathrm{h}_{\mathrm{FE}}$ Performance at $+25^{\circ} \mathrm{C}$

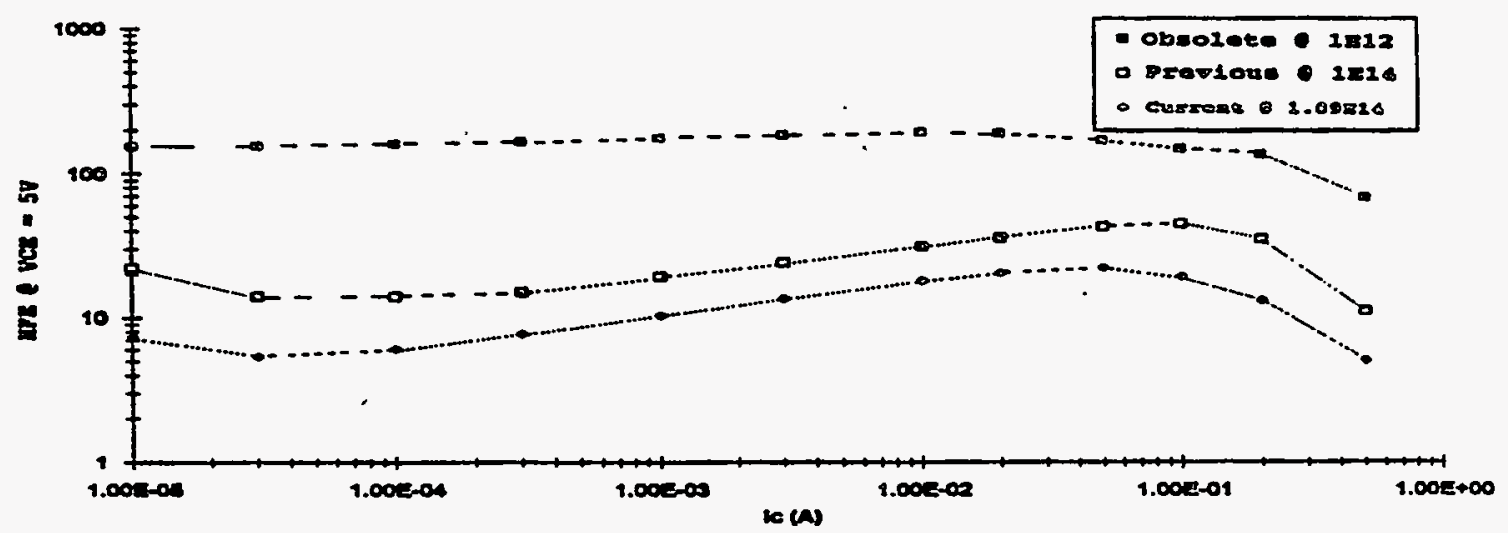

Figure B-2. 2N2907A Type Post-Neutron $h_{\mathrm{FE}}$ Performance at $+125^{\circ} \mathrm{C}$

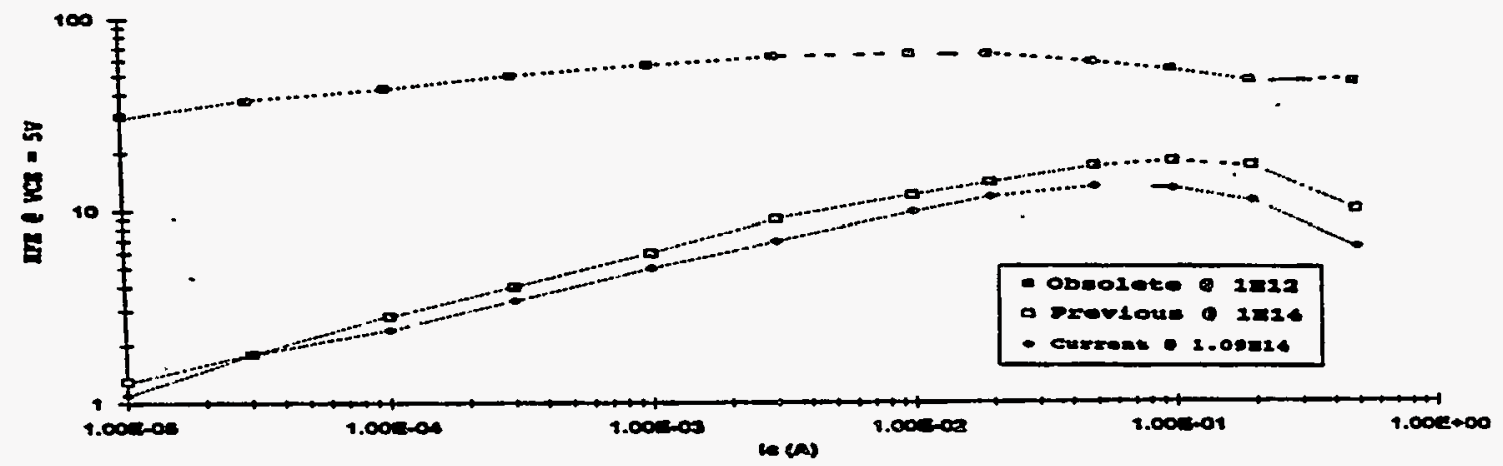

Figure B-3. 2N2907A Type Post-Neutron $\mathrm{h}_{\mathrm{FE}}$ Performance at $-55^{\circ} \mathrm{C}$ 
Appendix C

2N5339 Type Post-Neutron $h_{\mathrm{FE}}$ Performance at $25^{\circ} \mathrm{C} / 125^{\circ} \mathrm{C} /-55^{\circ} \mathrm{C}$ 


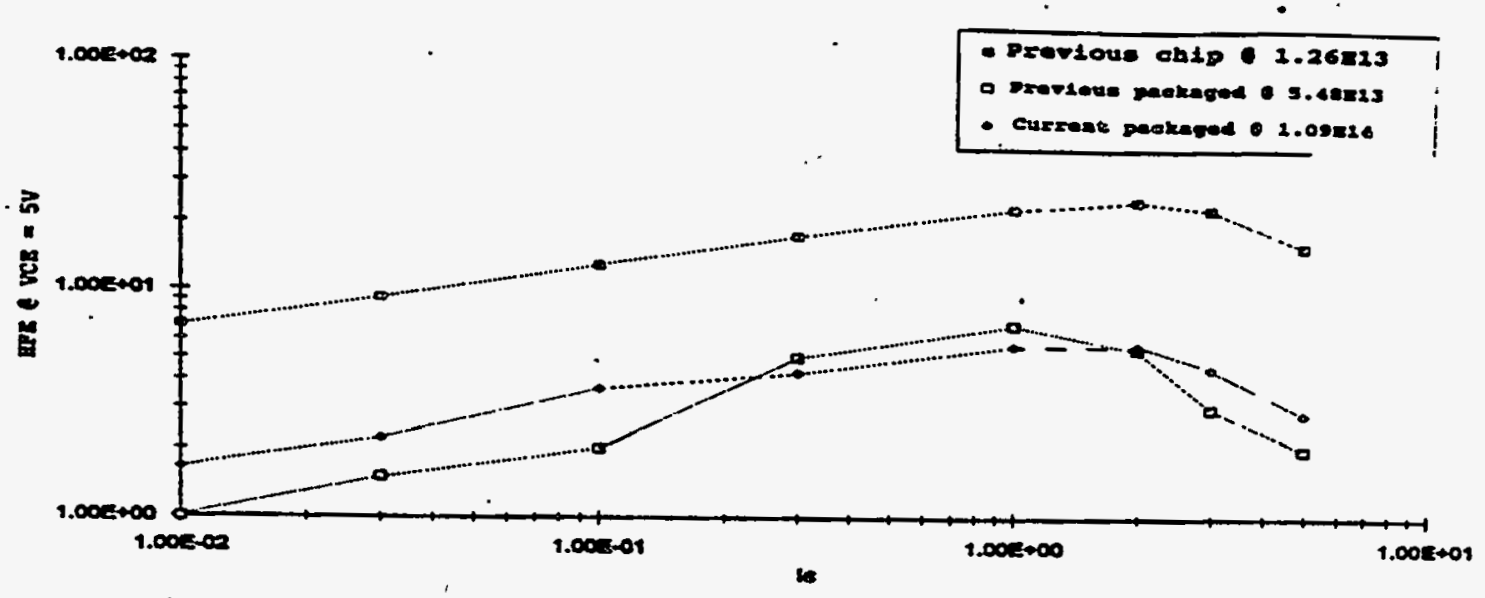

Figure C-1. 2N5339 Type Post-Neutron $\mathrm{h}_{\mathrm{FE}}$ Performance at $+25^{\circ} \mathrm{C}$

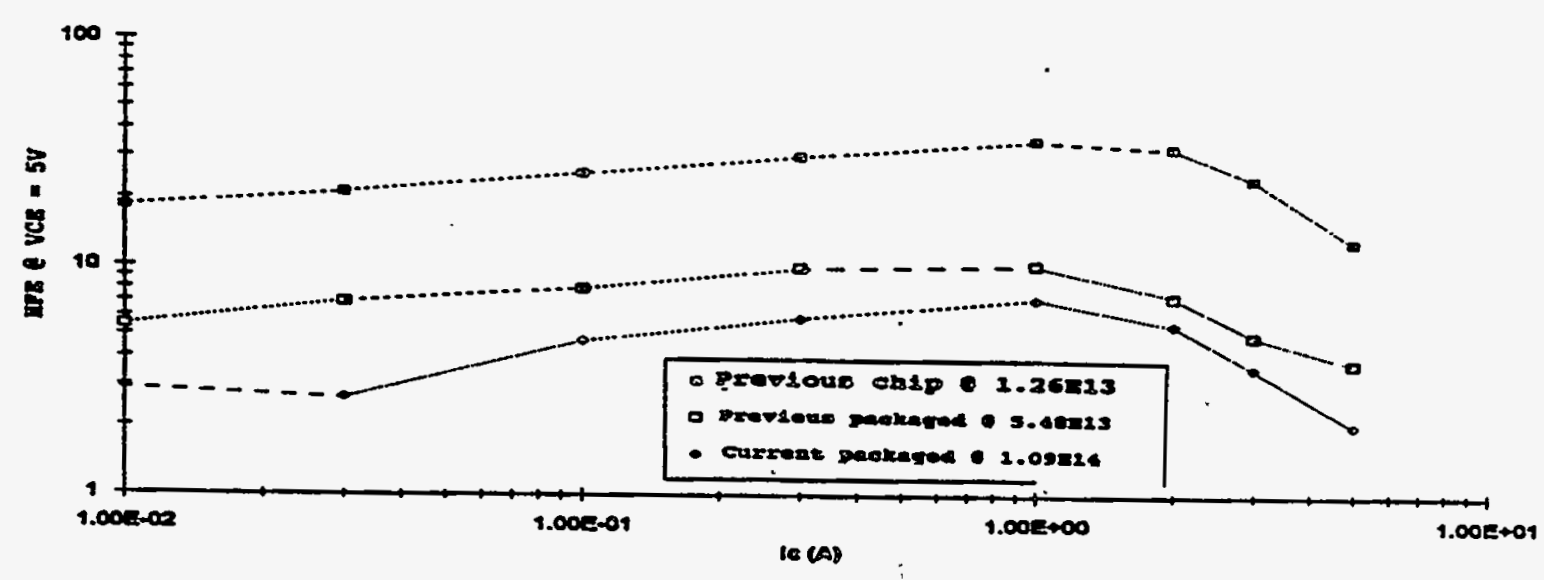

Figure C-2. $2 \mathrm{~N} 5339$ Type Post-Neutron $\mathrm{h}_{\mathrm{FE}}$ Performance at $+125^{\circ} \mathrm{C}$

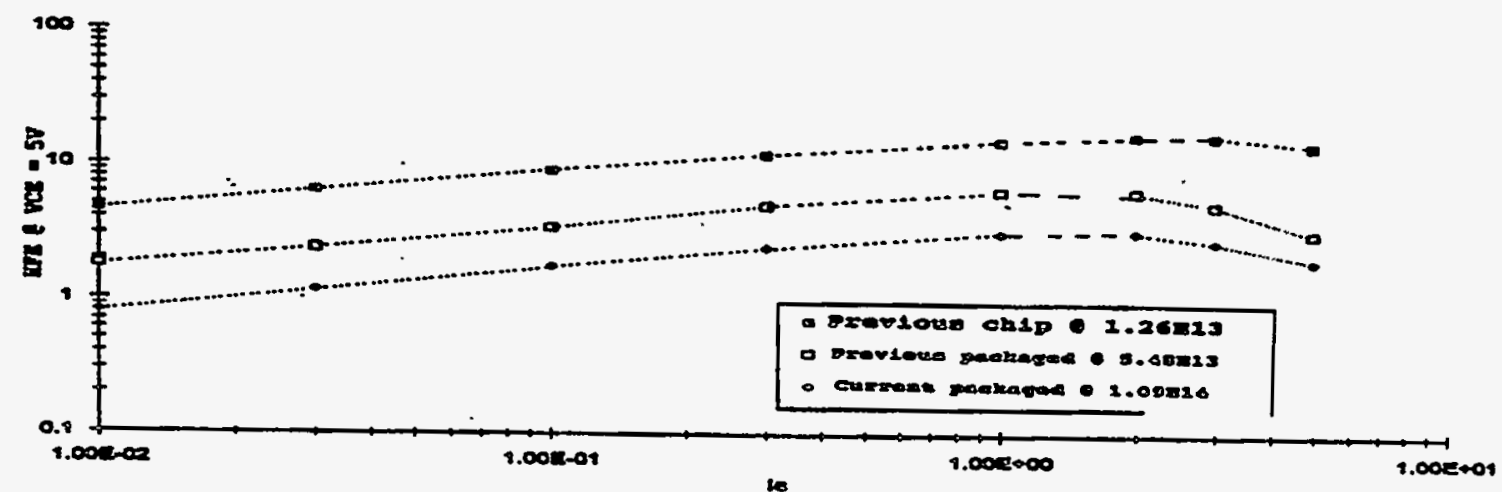

Figure C-3. 2N5339 Type Post-Neutron $h_{\mathrm{FE}}$ Performance at $-55^{\circ} \mathrm{C}$ 